\title{
Concepts of Mediology as a Synthetic Science of XXI Century
}

\author{
Natalia Borisovna Kirillova ${ }^{1}$ \\ ${ }^{1}$ Ural Federal University named after the first President of Russia B. N. Yeltsin, Russian Federation \\ Correspondence: Natalia Borisovna Kirillova, Lenina pr. 51, Ekaterinburg, 620083, Russian Federation.
}

\author{
Received: November 4, 2014 Accepted: December 4, 2014 Online Published: March 20, 2015 \\ doi:10.5539/ass.v11n8p173 \\ URL: http://dx.doi.org/10.5539/ass.v11n8p173
}

\begin{abstract}
Concepts of mediology as new synthetic science of XXI century have been analyzed in the article. Research field of this science is relatively wide. It covers paths of media culture development in new cultural reality, the problems of media semiotics and, tasks of media policy and media management as well as perspectives of media education. Mediology is not dogmatic but dynamic rapidly developing science. Possibilities of it become wider due to technical progress and processes that go on in social and cultural sphere of the outside world.
\end{abstract}

Keywords: concept, cultural reality, media reality, media culture, media semiotics, media philosophy, media policy, media management, media education

\section{Introduction}

In the course of social and cultural modernization of Russian society on the turn of XXI century special role of media culture as catalyst of numerous processes was revealed. It affects forming of new media environment, more open and democratic, that allows our society to enter informational and social and cultural space of the world. Media environment of post-Soviet Russia (global and local) is relatively complicated organism that covers various social institutions, social consciousness, spiritual and material culture, economy - everything that surrounds a man and help his socialization.

Visual culture consisting of TV (including cable and satellite TV), digital cinema and photo, multimedia, e-mail, computer channels and Internet as a (space of free communication) (M. Castells) leads in this process.

It also proves that we live in new social and cultural reality based on information. Even such a futurologists as A. Toffler who proved the power of media could not foresee the role of "Internet Galaxy" that consolidates a world into global information system.

Boundaries of study of media started to widen. Media science has gone a long way. In the first half of XX century two directions in study of this sphere appeared. The first scientific method was proposed by American sociologists and psychologists (Lazarsfeld, Simon, \& Green, et al., n. d.) and deals with defining the level of mass media on personality. Second direction had been developing in Europe, it is usually related with Frankfurt school of sociological research in Germany (Adorno, Marcuse, \& Horkheimer, n. d.) and activity of artistic critics (Leavis \& Thompson, n. d.) in Great Britain.

Now it is obvious that in XXI century the new science began to form that is medialogy. It is synthetic humanity laying on the basics of culturology, semiotics, philosophy of culture and pedagogics, political science and management. The term "mediology" was introduced by French politologists and sociologist R. Debray in 1990 to define new doctrine of technical means for knowledge and traditions transfer. This doctrine is covered in his book "Introduction ala Mediologie". In this work he proposed a range of new approaches and concepts for defining dynamic processes of communication in modern world.

But still the basics of mediology are in social and cultural and not in natural-scientific sphere. Research field of discipline is relatively wide. It covers the problems of media culture development, its system of sings and social functioning as well as its impact on modernization processes in society including the problems of personality socialization. One of the main tasks of mediology is the study of diversity and interaction of different cultures in global media space in ethnic and artistic levels.

Like any scientific discipline mediology has its system of scientific categories and concepts, its terminology that are forming in parallel with development of information society. 


\section{Media Culture}

The term (media culture) as a concept of the culture of information society was initially introduced to define (mass culture)based on the synthesis of technology and creativity.

Such theorist of culture and sociology as T. Adorno, R. Arnheim, A. Bazin, R. Barthes, W. Benjamin, J. Derrida, G. Deleuze, S. Žižek, M. Castells, H. McLuhan, H. Marcuse, N. Luhmann, J. Ortega y Gasset, M. Foucaulthave played substantial role in research of specifics and features of media culture development in Europe and the USA in XX century.

$\mathrm{W}$. Benjamin is considered to be one of the key figures of the process of rethinking of theory and practice of the culture of XX century and one of the authors of relevant conceptual language. As far back as in the middle of 1930s he defined the essence of problems that social theories on one hand and contemporary art and artistic criticism on the other hand faced. The most important affair for the latter was "unlimited possibilities of technical reproduction, disappearance of ontological and social boundaries between copy and original, breaking the "aura" of a work of art". Moreover, reproduction technologies released a work of art from tradition and replace its unique existence with "mass". Instead of individual consumption and aesthetic pleasure contemporary culture began to offer the more diverse and sophisticated forms of "mass consumption".

Research of H. McLuhan is the most important in this sphere. He is considered to be one of the first theorists of media. He devoted his works to analysis of communicative channels and researched everyday life of a man in information society that is the world created with the help of the newest means of mass communication. That was H. McLuhan who introduced the term (media) that soon became the synonym of the means of mass communication.

H. McLuhan's formula (Media is a message) is an axiom now. But according to McLuhan, media from the very beginning were aimed on capturing the consciousness of consumer immersing him in illusive virtual world.

J. Baudrillard, P. Virilio, F. Jameson stated hypertrophied character of audio and visual information. They considered media culture as a sector of culture related to translation of dynamic images that were widely spread due to modern technical way of recording and transfer of image and sound.

Analyzing different branches of the theory of culture R. Barthes in his work "Mythologies" indicated that new media characteristic for this or that society capture the consciousness of consumers by bringing them in their (semiotic system). One may find various cultural schemas, norms and values in this system that lays the foundation of society. That means that Barthes noted (mythological base of all types of media).

S. Žižek has original view of media. In his work (Cyberspace, or Unbearable seclusion of being) he wrote about media reality considering contemporary culture in the context of universal mediatizing that he views as the process of (turning of a real object into artificial one).

Media culture today is the intensity of information flow mainly audio and visual (TV, cinema, video, computer technologies, mobile communications, Internet, multimedia, etc.). These are means of complex adoption of the outward things with its social, moral, psychological, artistic, intellectual dimensions by a man.

All the above prove the conception of media culture as "an aggregate of information and communication means developed by mankind in the process of cultural and historical development that promote forming social consciousness and socialization of a person. It consists of production culture, the culture of information transfer and the culture of information perception; it can be an indicator of the level of development of a person capable of perceiving, analyzing, assessing this or that media text, be engaged in media creation, adopt new knowledge via media".

Media culture is multifunctional phenomenon that develops together with society in the context of its social and cultural modernization. Moreover, media culture is multifunctional. It means that its role in society is unique. The following important functions that make media culture a phenomenon of information age should be noted: information function, communication function that is closely connected with information one; normative (ideological) that is represented by the fact that media culture is responsible for the process of personality forming, for adoption of social experience, knowledge, ideals by personality; relaxing; creative function that is related to adoption and transformation of world, of life, of habitat; integrative function that is aimed on joining cultures for the sake of world and common understanding of the peoples of the Earth; mediation function that is represented in the fact that media culture acts as a mediator that develops connections between different structures of society and social groups. 


\section{Media Semiotics}

Media semiotics is a special concept of mediology (from Greek semeiotike - sign, characteristic). Language of media culture as a system of signs is the subject of media semiotics.

Semiotics is based on the works of philosophers of the turn of XX century C. Peirce and F. de Saussure. They were the first who researched the nature of language and gave the beginning to the new scientific discipline studying all systems of signs.

Numerous foreign and Russian scientists such as R. Arnheim, A. Bazin, R. Barthes, M. Bakhtin, V. Bibler, J. Baudrillard, L. Vygotskii, M. Kagan, C. Lévi-Strauss, Yu. Lotman, Yu. Kristeva, K. Razlogov, Yu. Tynianov, U. Eco, R. Jakobson, M. Yampolski, et al. Methods that they have proposed are applicable for general analysis of media. These methods are also applicable for analysis of the language of media.

From information and semiotic point of view media culture has three aspects: the system of artifacts (from Latin - arte - artificial and factus - made), the system of symbols and signs. "Any system that serves communication purposes may be defined as language", wrote Yu. Lotman. Applying methods of linguistics to analysis of the language of the works of art Lotman proved that "any cultural phenomenon should be viewed as texts that contains information and meaning".

As text is a polysemantic concept not only written information should be considered (book, newspaper or magazine article) but any carrier: cinema, TV or video movie, radio or TV program, computer file, Internet site and so on.

Media text had its own course of development like all the system of mass communications. H. McLuhan defined four following epoques in the history of civilization and thus in the history of media culture: 1) preliterate epoque of barbarism; 2) phonetic writing millennium; 3) "Gutenberg Galaxy" i.e. five hundred years of printing technologies; 4) "Marconi Galaxy" i.e. contemporary electronic civilization. One may add fifth element in the list that is "Internet Galaxy" as Castells has defined it.

New media appeared every time as a mean of realization of the two most important necessities of a man: they promise greater freedom of choice and the freedom of interaction with outward things.

So the foundation of media culture is signs and aggregates of signs ("texts") with "encrypted" social information that means their content, meaning, sense.

According Bakhtin's theory text may be ideological but only in the case it has the foundation: "the unity of consciousness" and the unity of speaking ego that guarantee validity of this or that ideology. "Bakhtin marks the most important boundary between ideology and text", Yu. Kristeva wrote. According to Kristeva text is always polyphonic and consequently has no internal ideology because it has no ideological subject. That is why text is a "site that various ideologies enter to bleed white each other in fighting".

Works of Kristeva were sensational in due time because she introduced term "intertextuality" in semiotics. It is a key term for post-modern aesthetics and defines special dialogical relations of texts that are building as a mosaic of quotations. So texts of media culture preserve social memory (codifying reality). At the same time the system of signs of each group of media culture types is individual. (Sign as it is interpreted by social philosophy is a thing used for replacement and representation of the other thing (property or relation) and used to keep process and transfer the message. Sign is an inter-subjective mediator, structural mediator in society).

Yu. Lotman defined five following functions of artistic text: 1) message of the bearer of information to a subject; 2) collective memory capable of continuous augmentation; 3 ) interaction of a subject with himself, in this way text actualizes some personality features; 4) text becomes an interlocutor; 5) interaction between text and cultural context.

Written language tends to develop its own structural features. It gives Yu. Kristeva, the follower of M. Bakhtin, the possibility to have a look on "the other side of language" and reveal "pre-verbal" level of object's existence. The unconscious has unlimited power here. Kristeva further turned to destruction of monolithic institutions of sign and shifted her own interests from linguistics and semiotics to "sema-analysis". According to Kristeva, text should be dynamized, differentiated, the boundary between "gene-text" and "pheno-text" should be marked. These features of text correlated like surface and depth, symbolism and formula.

There is essential difference between audio and video media. Sound, speech, music, vocalism plays leading role as structural factor in first systems that includes radio, gramophone, tape-recorder, CD-ROM, etc. Time is important factor here and it is represented in two dimensions - succession and simultaneity. Structuring of the second is related to space. In traditional visual arts (painting, graphic arts, placard) iconic systems of signs 
dominate.

Technical media culture that reproduces the reality is related to "photogeniety" that is the aesthetic of a frame. It is not only the feature of photography but the most effective audio and visual means of communication (cinema, $\mathrm{TV}$, video, animation, computer technologies, etc.).

While letter, word are the base of the system of signs in written culture, the basic "brick" of audio and visual culture is frame. There are photographic, cinematographic and TV culture of a frame depending on the way "introduction" in "event flow" is made.

Photographic frame culture is related to using photo-frame that communicates impression of real event.

Cinematographic frame culture uses frame as an "arrangement cell" (S. Eizenshtein) that allows to communicate not only direct impression of event, but its meaning.

TV culture is related to such way of using frame that allows a viewer to be directly introduced into "event flow" and see if "from inside".

New aesthetic of audio and visual creativity has emerged on the base of screen technologies that has been further developed as a new form of a language of culture - "the culture of frame".

\section{Media Philosophy}

The concept of media philosophy (the philosophy of media culture) is based on the junction of culturology, theory of communication, semiotics and philosophy. Media philosophy differs from the theory of communication or media semiotics in the fact that "media philosophy does not ask the question of a certain mechanisms, processes or means of communication. Its subject is a construction of individual and social body, means of perception, motivation and activity of a man under the conditions of new media".

Ontological dimensions of media as a system of communicative means are object of media philosophy. Ontology (from Greek - matter) is the study of existence, of the principles of its construction, laws and forms. "Social ontology in modern interpretation is the doctrine of existence of society that included the doctrine of a man, of human individuals interdependent in their self-fulfillment", V. E. Kemerov wrote.

In this regard any branch of media philosophy has ontological character including study of media reality. Considering the problem of the power of media reality one may understand that "ontology of communications turns into communicative ontology, so it is possible to speak about media philosophical space".

Answers on numerous philosophical questions as a foundation of knowledge of world such as what is life? What is existence? What is an essence? What is time? What is reason? Etc. has been interpreted in XX century not only via science and art but with the help of media: initially with newspapers and magazines, than cinema, radio and $\mathrm{TV}$, and on the beginning of XXI century with the help of global computer networks. In became obvious that there is a dramatic difference between scientific understanding of world and its calque represented in the content of media information. It is caused by objective and subjective reasons.

That is why research of media reality as new social and cultural habitat of a man is one of the tasks of media philosophy. This habitat is parallel, virtual world sometimes perceived as objective reality.

M. Castells thinks that we live in the situation of a special culture that is "virtual because it is based mainly on virtual processes of communication managed by electronics... This virtual space is our reality. That is specific factor typical for the culture of information age - we fulfill our creation of meaning via virtuality".

But the world of virtual reality is nothing more than simulacrum (from English simulare - to pretend to). It is one more term of post-modern aesthetics that is represented in the works of J. Baudrillard, G. Deleuze, J. Derrida. Simulacrum is a "copy of copies", fake, fiction. Simulacrum is based on discrepancy, on the difference of "the truth" and "the lie", "real" and "unreal".

Specific of media reality is that it is deeply mythological i.e. based on myths.

Today man undoubtedly consider himself a rational being but his ideas of the outer world has obviously mythological character at the level of the (unconscious) irrespective of a man himself. German philosopher E. Cassirer explained this phenomenon and wrote that (man does not oppose reality directly; he is not faced with it...). At the same time a man cannot live in a world without strict facts or in accordance with his direct wills and necessities. He lives rather in imaginary emotions, hopes and fears, in illusions and losts of these illusions, in his own fictions and dreams). In other words there is always some mediator between reality and a man who helps individual to adopt reality and to develop his attitude to it. One of such forms is media and another is myth (from Greek mythos - legend, saga) that is fiction, illusion that may be used to wrap reality in. 
R. Barthes paid special attention to this function of media.

So means of mass communication i.e. Media not only create new mediareality but also myths that allows a man to perceive reality. But myths create also a man himself because they affect his world view, ideals and promote the process of his socialization.

\section{Media Policy}

Media policy concept is related to the system of managing media sphere that deeply depends on the level of social and economic development of society, its legal and political culture, interaction of state and business, specifics of media market, etc.

In UNESCO project (Declaration human rights and the rule of law in the Information Society) information and communication technologies (ICT) are recognized as (driving force of building of information society). It is also stated that (implementation of rights and freedoms fixed in Convention (ECHR) should be supported for everybody without exception irresponsible of used technical tools).

Rapid development of legislation on he means of mass communications started in 1990s when a number of law were passed that laid the foundation of media policy in the country.

The core of it is On Means of Mass Information Law of Russian Federation of 1991. The main idea of On Means of Mass Information Law is freedom of press and inadmissibility of censorship.

Philosophy of the freedom of press released from control of authorities and serving civil society promoted development of numerous democratic institutions. Main synopsis of the Law of 1991 was included in the Article 29 of the Construction of Russian Federation (1993).

The On Legal Protection of Programs for Electronic Computing Machines and Databases Law of RF of 1992 was passed for protection of intellectual property in 1992 and a bit later On Copyright and Allied Rights Law of July, 1993 (corrections to this law were made in 1995). One more act On Information, Informatization and Information Protection Law of February, 1995 that set legal guarantees of development of informational space of Russia.

On State Support of Cinematography of Russian Federation Law of 1996 was passed that founded specifics and functions of producer activity for the first time in Russia and gave the possibility for Russian cinema to widen its technical, economical and creative possibilities.

In 1997 President of RF signed On Transition of Russian Federation to Information Society Order that initiated working out such specialized documents as Conception of National Security of Russian Federation, Conception of State Information Policy, Conception of Foreign Policy of RF, Doctrine of Information Safety of Russian Federation (passed in 2000). The essence of all these documents is that development and ubiquitous introduction of modern high technologies have increased volunerability of society and the state. Both positive and negative information influence not only on individual person but society as a whole has increased due to the process of informatization that covers almost all the world and that is based on mass introduction of information and computer technologies.

Top-priority task of media policy became modernization of social and cultural sphere including:

- Computerization of libraries, museums, archives;

- Development of public databases and banks of data in liberal and social sciences;

- Development of wide net of cultural and informational and informational and entertaining centers in regions;

- Introduction and development of Russian sector of Internet, technological support of authority's and state administration's sites, sites of political parties and social movements;

- Support for information security of personality, society and state.

Russia's entering the Council of Europe set the problems of compatibility of Russian and international legislation in social and cultural and media sphere. It concerns some articles of UN Charter and UNESCO Charter, UNESCO Declarations, Acts of the Council of Europe and others.

Culture including media culture in these documents is interpreted as necessary condition of realization of creative potential of personality and society as a form of strengthening of unicity of people and the foundation of spiritual health of a nation, as humanistic milestone and criteria of development of a man and civilization. 


\section{Media Management}

The process of reforming of Russian society on the turn of XXI century, shift from planned economy to market economy, realization of a certain independence of institutions of culture in situation of decentralization and privatization, focusing on development of consumer market including media market (mass print press, publishing, films and video production, TV and radio programs, multimedia production, Internet publications, network art, etc.) required active development of theory and practice of management in situation of market economy.

Management is the science of managing this or that sphere. Media management subject is the system of management of information and communication sphere aimed on the process of development of media culture of society.

New management culture is being formed in today Russia. Essence of this culture is special role of rational principles: information, knowledge, scientific design, social modeling.

Management in information and communication sphere is capable of streamlining media processes and increases their efficiency in society basing on media policy of the state.

Conception of media management is universal term that denotes: 1) social and economic institution that influence way of life, sphere of culture and policy, entrepreneurship; 2) people, engaged in management of intangible, spiritual production and distribution of media products (newspapers, magazines, books, films, TV and radio programs, network works of arts, multimedia, etc.; 3) scientific discipline studying technical and organizational and social and economic dimensions of media sphere management, processes of production and consumption of information, influence of ICT on society, etc.

One of the most important problems of media management is the level of manageability of media space. The answer on this question depends on a number of reasons: 1) maturity of civil society; 2) state media policy; 3) level of media culture of society, level of media education of citizens; 4) economics; 5) system of functioning of various social institutions that support balance in society, and others.

Mechanisms of media management are defined by aims and tasks of state regulation: political, legal, economic, social and cultural. These are planning, design, foundation of media organizations (publishing houses, information agencies, TV channels, editorials, studious, cultural and entertaining centers, etc.) their constant innovation, technological modernization, widening of media space and media market, realization of creative potential, professional training of specialists, media education of consumers, etc.

All the above prove that media management is integrating system. From the point of view of media management integration is all the process of interaction of various media structures and organizations with state and society, environment, end markets, marketing system and PR technologies, science and education, etc.

Culturological dimension of integration plays special role now because development of effective media structure is eventually brought to joining different sub-cultures via development of common aims, common language and common procedures of decision making.

Study of media management like other concepts of mediology is caused by demands of contemporary society as well as perspectives of development of common social and cultural space of the country and the world as a whole that promotes spiritual development of personality of XXI century.

\section{Media Education}

Media education concept is the most important both for pedagogical sphere and for social and cultural life.

According to UNESCO materials media education is studying theory and practical skills to master modern means of mass communication, viewed as a part of specific autonomous sphere of knowledge in pedagogical theory and practice. One should distinguish it from using media as supporting tools for teaching in other spheres of knowledge such as mathematics, physics and geography.

Both our country and foreign countries have experience of media education. There are numerous media schools in the world, pedagogics study and masters their main concepts and models.

Media education is complex process comprising several disciplines including not only pedagogics and psychology but culturology, sociology, economy, art studying disciplines.

The following directions of media education may be defined now: 1) media education of future professionals (journalists, script writers, directors, cameramen, editors, media critics, managers, producers, etc.); 2) media education of future pedagogue in universities and pedagogical higher educational institutions, in the system of 
professional training; 3 ) mass media education as a part of general education of school-children and students studying in schools, colleges and higher educational institutions; 4) media education in cultural and entertaining centers; 5) remote media education via TV, radio, Internet; 6) self (continuous) media education that may be realized during the whole life. Media pedagogics deals with all these problems.

Main aim of media education is forming media culture of a person, its socialization, developing of critical thinking, capability to dialog and managing political and social and cultural sphere.

Only complex training may allow young people to enter info-sphere as fully fledged specialists of XXI century theorists and pedagogue, methodologist of cultural and entertaining centers, expert analysts on problems of mass media and managers of social and cultural sphere.

\section{Conclusion}

Having analyzed the main concepts of mediology as synthesis of sciences we may define tasks that should be solved by this new science in the coming years:

1. Further development and study of categorical instruments and the structure of mediology in the context of processes of modernization of society.

2. Study of social and cultural factors influencing forming of new media reality.

3. Increase of the role of media culture as a mediator between the state and person, between authority and society, different social strata, countries and continents.

4. Improvement of legislative base of media policy of a state as catalyst of its efficiency.

5. Development of practical base of media management as integrator of the media of Russian modernization.

6. Widening of possibilities of media education that promote socialization of personality, forming pluralistic views, tolerance and mutual understanding of people and states.

\section{References}

Bakhtin, M. (1963). Problems of poetics of Dostoevski. Moscow: Sovetski Pisatel.

Barthes, R. (2008). Mythologies. Moscow: Academicheski Prospekt.

Benjamin, W. (1996). Work of art in the era of its technical reproduction. Selected essays. Moscow: Medium.

Cassirer, E. (1945). An essay on man. An introduction to a philosophy of human culture. New Haven, L.

Castells, M. (2001). The Internet Galaxy. Reflections on the Internet, Business and Society. Oxford UP. http://dx.doi.org/10.1007/978-3-322-89613-1

Castells, M. (2000). The Rise of the Network Society. The Information Age: Economy, Society and Culture (2nd ed.). Oxford, UK: Blackwell.

Debray, R. (2000). Introduction a la Mediology. Paris.

Declaration of human rights and the rule of law in the Information Society. (2005). Moscow. Russian Commettee of UNESCO Program (Information for Everybody).

Delluc, L. (1920). Photogenie. de Brunoff.

Eizenshtein, S. (1956). Selected articles. Moscow: Inskusstvo.

Kirillova, N. (2008). Media culture: Theory, history, practice. Moscow: Academicheski Prospekt.

Kirillova, N., \& Khilko, N. (2011). Audio and visual culture. Vocabulary of terms and concepts. Ekaterinburg, URFU.

Kostina, O. (2008). Ontological dimension of communications. Saint-Petersburg, Filosofskoie Obschestvo.

Kriseva, Yu. (2004). Breaking down poetics. Selected works. Moscow: ROSSPAN.

Lotman, Yu. (1994). About art. Saint-Petersburg: Iskusstvo.

Lotman, Yu. (1998). The Structure of Artistic Text. Saint-Petersburg: Iskusstvo.

McLuhan, M. (2005). Understanding Media: The Extensions of Man. London: Taylor \& Francis Group.

Media Edication. (1984). Paris: UNESKO.

Peirce, Ch. S. (1955). Philosophical Writings of Peirce. NY, Dover Publications; Saussure, F. de. Worksinlinguistics. Moscow: Progress. 
Savchuk, V. (2008). Media philosophy: Forming of the discipline. Saint-Petersburg: Filosofskoie Obschestvo.

Social Philosophy. Vacabulary. (2003). Moscow: Academicheski Prospekt.

The Media: An Introduction (2nd, ed.). (2002). Pearson Education Limited.

Toffler, A. (1990). Power shift: Knowledge, Wealth and Violence at the Edge of the 21st Century.

Žižek, S. (1998). Cyberspace, or Unbearable seclusion of being. The art of cinema, 1.

\section{Copyrights}

Copyright for this article is retained by the author(s), with first publication rights granted to the journal.

This is an open-access article distributed under the terms and conditions of the Creative Commons Attribution license (http://creativecommons.org/licenses/by/3.0/). 